\title{
Health Insurance System Revision in the Czech Republic, Finland, France, Germany and the Slovak Republic
}

\author{
PaedDr. Zuzana Horváthová, Ph. D. \\ Department of Law and Public Administration, Metropolitan University Prague \\ zuzana.horvathova@mup.cz
}

Assoc. Prof. Ing. Josef Abrhám, Ph. D.

Department of Law and Public Administration, Metropolitan University Prague

josef.abrham@mup.cz

Doi:10.5901/mjss.2015.v6n2s5p286

\section{Abstract}

Widely used terms such as the European social model and the European social policy are not entirely accurate. Social policy belongs among the areas where the competence is shared between the Union and the Member States. Thus the European social model can be defined more as common values and social foundations, which are typical for the European area. Among the Member States are therefore substantial differences in terms of the set-up and functioning of social, health and pension systems. The aim of this paper is to evaluate the treatment of health insurance and selected aspects of health systems in selected EU countries (Czech Republic, Finland, France, Germany and the Slovak Republic), and on the basis of mutual comparison to draw up recommendations for the implementation of social policy instruments at the national level and also to explain examples of good practice. The solution-seeking methodology is based on literature research, analysis of legislation in different countries and analyses of empirical statistical data from the social systems.

Keyvwords: social policy, welfare state, health insurance, states of the European Union

\section{Introduction}

At present, social security is one of the most important attributes of running the society and its wording is defined in the Charter of Fundamental Rights of the European Union. We can say that the official definition of social security does not exist because every multinational corporation as well as states define the concept of social security in a different way.

The aim of this paper is to highlight the diversity of social systems in selected countries of the European Union and in general in the European region. Although the European Union has a unified social policy for each state, still there are differences in the individual countries in all areas of social security. We will focus mainly on social security from the perspective of health insurance. The proceeding compares in detail the selected European countries in the area of health insurance, and especially highlights the advantages and disadvantages of a given state in this area.

More than 30 years ago, Zacher (1976) defined a social right as a right that compiles all branches of law, which are characterized by increased intensity socio-political content.

According to Tomeš (2010) one should include among the goals of the contemporary social security both the regulation of a citizen's responsibility for their future as well as the setting of the extent and forms of social solidarity among citizens.

Social security can be characterized as a system that provides people with legal and financial support in difficult life-time situations. Another way is to define the term social security as an arrangement that defines and provides alternative sources and the relative balance of levels of social security and sovereignty in different forms:

- social benefits (insurance, pays/benefits)

- social services (advisory, services)

- social asylums (retirement homes, children's homes) ${ }^{1}$

All current EU Member States have their own social security legislation. At the same time, each State itself decides on the creation of a national social security system, on the individual benefits, the funds and the rules under which the

${ }_{1}^{1}$ Krebs, V. a kolektiv. Sociální politika. 3. prepracované vydání, Praha: nakladatelství ASPI, a.s., 2005. s. 158,159 
benefits will be provided and in what amount it will contribute to individual insurance.

Among European principles of the social security coordination one can include:

- principle of equal treatment assumes the prohibition of any discrimination on grounds of nationality;

- application of the single state law takes force in the applications of the laws of the State in which the activity is carried out, regardless of the place of residence;

- aggregation of the insurance periods says that the law applies, if in a given Member State the social benefit depends on the insurance period;

- maintenance of the acquired rights: the payment of benefits in any other Member State shall be provided in accordance with the Regulation

- assimilation of facts: facts and particulars that occurred in another state and are also taken into account in the State of insurance. ${ }^{2}$

\section{Areas of Social Policy as a Part of a Welfare State}

Social support, or in the past used expression the social advancement, is the system of providing cash benefits defined by law to those who fulfil the conditions of the entitlement. At present, it is mainly the benefits that are provided to certain groups of people from the state budget and those people did not contribute by paying financial contributions.

Svoboda (2011) presents a social security at the level of primary law of Art. 48 of the Treaty on the Functioning of the European Union.

Most countries of the European region use the concept of social security. According to Tomeš (2010), this concept can be characterized as a regulation of a citizen's responsibility for their future as well as the setting of the extent and forms of social solidarity among citizens.

Social policy has six basic areas:

- Employment policy: employment is a very important element in the overall economic situation of the country and one of the most important aspects of social policy. The society classifies certain jobs positively or negatively and this affects the perception of a person. At the same time, unemployment may entail a certain social stigma;

- social security policy: it is well known that for the poors a certain level of social assistance has existed since the Middle Ages; greater increase in social security comes at a time of industrialization when labour migration from rural to urban areas takes place and thus social family ties or care for the ill are broken. At present, each state has a different social system, which is dependent on the economic stability and the level of development of the state. However, every social system of both the rich countries and countries with economies in transition has two basic categories of support. The first category covers unemployment and illness payments, and in the second group there are included benefits to cover medical care and child care;

- health care policy: its partial aim is a reconsideration of the question of whether the protection of health should be covered only by individuals. Almost immediately such a view is refused, since the quality of human health depends not only on the person, but to a large extent on interpersonal relationships, and in order not to put human health in a threat, a certain carefulness of other individuals is required, who should behave so as to prevent the spread of diseases and other health damage. A good health policy is not limited to health care, but it tries to influence the activities of all the sectors of the national economy; ${ }^{3}$

- education policy: education directly expanded with the economic situation of the state and the overall industrialization of the region, from which we can infer that the more developed economies, the more resources for education and the more educated labour force, the more advanced economy. ${ }^{4}$ Developed states try to provide the possibility of lifelong learning at all levels of the population, regardless of the financial situation of their citizens and every citizen should have an access to education - democratization of education;

- housing policy: for every citizen is important to have a place to stay because without dwelling they have no access to sanitation possibilities, rest facilities, storage of property and dignified living. Housing policy should be part of a strategic planning, if a region is experiencing increasing jobs and construction of industrial

\footnotetext{
${ }^{2}$ Elaborated by the EU and International Cooperation Departement of the Ministry of Labour and Social Affairs. Sociálni zabezpečeni osob migrujicích v rámci Evropské unie: výběr textů vztahujicích se $\mathrm{k}$ základním předpisům. 1. vydání, Praha: Ministerstvo práce a sociálních věcí. 2009. s. 8, 9, 10, 11

${ }_{3}^{3}$ Potǔčck, M. Sociálni politika. Praha: SLON, 1995. s. 85

${ }^{4}$ Potũček, M. Sociálni politika. Praha: SLON, 1995. s. 87
} 
enterprises, there must also be newly built flats because of labour migration. The goal of housing policy is mainly to satisfy the needs of families, often several generations, the needs of young people looking for housing to be able to start a family, the needs of individuals and underprivileged citizens; ${ }^{5}$

- family policy: it should serve as a tool to support all the natural functions of the family as the basis of the state and society. It should not be focused and motivated only by population targets but its primary aim must be the elimination of a comparable disadvantaging of families.

\section{Sickness Insurance and Its Legal Provisions in the Czech Republic}

Sickness insurance serves to financial security of the economically active persons in case of adverse social events in a person's life, such as illness, injury, pregnancy or maternity. Under the fulfilment of the conditions stipulated by law it arises directly from the Act and all health insurance benefits are therefore obligatory. ${ }^{6}$

The first part consists of a system of social insurance pension and sickness insurance, which are managed by the Czech Social Security Administration, and of the system of the health insurance ${ }^{7}$ managed by health insurance companies.

The second part of the state social security system consists of state social support ${ }^{8}$, which is part of the Labour Office and is within its full responsibility through its regional offices. The principle of a state social support system is based on high income solidarity. State social supports address social situations where the aim of this assistance is to efficiently support the family, especially during a child birth, child care or the death of the breadwinner.

The last part of the social security system includes social assistance system. ${ }^{9}$ This type of assistance is provided to persons in difficult life situations, i. e. in material or social need. The method of social assistance always depends on the individual situation and it is possible to divide it into social services, assistance to persons with disabilities and assistance in material need.

Every State, which is a part of the European Union, shall coordinate the social security system and its primary objective is to eliminate any discrimination, to ensure the maintenance of acquired rights and to apply the principle of the single state law. It follows that the European Union applies the principle of one insurance.

A person who has permanent residence in a Member State of the European Union and Switzerland is entitled to receive medically necessary healthcare in another Member State. He draws the care provided to the same extent as the citizens of the given State - local insurance holders. The only thing is that a given EU citizen must hold a European Health Insurance Card.

A person who is a permanent resident within the European Union, but wants to get an execution of the planned health care within the European Union outside his country of residence, may do so in the event that medical care would not be otherwise provided in a sufficient period of time. In this case, however, it is necessary to submit insurance agreement with his insurance company concerning the reimbursement of care needed. ${ }^{10}$

The Czech Republic provides its citizens with four kinds of sickness benefits:

- maternity support (receive financial pay-off benefits);

- sick pay (receive financial pay-off benefits);

- balancing allowance in pregnancy and motherhood (receive financial pay-off benefits);

- nursing pay (receive financial pay-off benefits).

The Czech Republic is a member of the World Health Organization (WHO), which grants every person the same rights, duties and shared responsibility for health. It also declares to every citizen of the Czech Republic his dignity and his value. It puts as the primary goal the improvement of health and wellbeing of people with the aim of social and economic development. "Members of the WHO build the Declaration on ethical principles of justice, solidarity and social justice and emphasize the importance of reducing social and economic inequities in improving the health of the whole population". ${ }^{11}$

\footnotetext{
5 Potůček, M. Sociálni politika. Praha: SLON, 1995. s. 97

6 TRÖSTER, P. Právo sociálního zabezpečení. Praha: C. H. Beck, 2010. s. 149. ISBN 978-80-7400-322-6.

7 TRÖSTER, P. Právo sociálního zabezpečení. Praha: C. H. Beck, 2010. s. 135. ISBN 978-80-7400-322-6.

8 TRÖSTER, P. Právo sociálního zabezpečení. Praha: C. H. Beck, 2010. s. 253. ISBN 978-80-7400-322-6.

9 TRÖSTER, P. Právo sociálního zabezpečení. Praha: C. H. Beck, 2010. s. 358. ISBN 978-80-7400-322-6.

10 https://www.euroskop.cz/582/sekce/evropsky-prukaz-zdravotniho-pojisteni/ [2013-02-03].

11 http://www.nszm.cz/cb21/archiv/material/Svetova_deklarace_zdravi.pdf [cit. 2013-02-07]. 


\subsection{Selected Differences in Individual Countries}

Every Member State of the European Union has built its own social security system, which is based on certain tradition of social security and lifestyle of the inhabitants of the State. Sickness insurance ensures the insured persons in case of temporary employment incapacity, regulation quarantine, pregnancy, maternity and nursing of a household member or a care for him. ${ }^{12}$

\subsection{The Czech Republic and Finland}

Compared to the Czech Republic, where the sickness rate is fixed and makes $60 \%$ of the daily assessment base, in Finland the rate is based on the annual earnings of the insured person. The higher the annual earnings of the insured person, the smaller the percentage of the assessment base, which begins on the amount of $70 \%$ of annual earnings. But there is also set a specified minimum daily limit, which makes 2. 60 Euro.

The support for the treatment of a child under the age of 16 years makes in Finland up to 60 days, unlike the Czech Republic, where treatment time is only 9 days. In case of a serious illness of a child the support can be increased up to 90 days.

Just as in France the Finnish state social system lacks the possibility of payment of compensatory allowances for maternity and pregnancy, but in the Czech Republic this is paid.

In the Czech Republic both the employee and employer (a fixed amount from his profits) contribute to the health insurance. In Finland such a system does not exist, as the employees do not contribute from their salary for health insurance, there.

The Finnish pension system is divided into two groups, i. e. statutory and state pensions. The statutory disability pension is awarded to persons who have a reduced ability to work down to at least $60 \%$ and is also limited by the age of the applicant, who must be between 18-62 years old.

As for the disability pension there exist either a partial or full disability pensions. The degree of a given type is assessed on the basis of the state of health of the insured person and the entitlement to a state disability pension is limited by the age of the applicant, who must be between 16 and 64 years old.

Up to 2009 the disability pension in the Czech Republic was divided into a partial and a full one. At present, with the reform of the health care, disability pension may have three stages (first, second and third degree). The entitlement to receive a disability pension exists for individuals who meet two basic assumptions which are the required insurance period and the recognition of invalidity.

\subsection{The Czech Republic and France}

In France, sickness benefits are paid only from the contributions from employers and insured persons while in the Czech Republic these benefits are paid out from contributions of the employers, insured persons and state subsidies.

In the Czech Republic, the employer pays contributions to the system of sickness insurance, from which are paid sickness benefits at the amount of 2. 3\% compared to 12. $8 \%$ in France. In the course of the illness the support period in France starts from the 3rd to the 7th day and may last up to the 365th day. From the insurance company the citizen gets the height of a $50 \%$ and additional $40 \%$ from the employer. In the Czech Republic the support period starts from the 22nd up to the 380th day.

Nursing pay in the Czech Republic is paid out for a maximum of 9 days for single parents, but parents may once switch and so the total length of nursing pay may be 18 days. In France, the length of nursing pay is paid according to whether the parent stays home, or just limits his working hours due to taking care. If the parent stays at home he is entitled for support for 24 days at the amount of 53.17 Euro per day. When he just limits the working hours the nursing time is extended up to 42 days and the amount makes 26.58 Euro per day.

Compensatory contribution during pregnancy and motherhood in the Czech Republic is calculated in the proportion to the previous income and to the income in the situation that has arisen due to pregnancy or motherhood. It is paid for a maximum period of nine months after the birth. In France, this type of social contribution does not exist.

Family policy, although not included in the health insurance, is a part of the social system in France and is aimed at supporting families with many children. Maternity allowance is paid at the intensity of $100 \%$, which can be seen as a successful motivator the policy of reproduction.

${ }^{12}$ see § para 1 Act No. 187/2006 Coll. On Sickness Insurance as amended 


\subsection{The Czech Republic and Germany}

Czech social insurance includes pension, sickness and health insurance. The fourth type of insurance, the unemployment insurance, is a part of the state employment policy and is not a part of social insurance. The Employee Accident Insurance Act 2006 came into force only this year. The sickness insurance scheme provides citizens with sickness benefits, maternity and nursing pays and compensatory allowance in pregnancy and maternity.

German social security system is composed of sickness insurance, pension, accident insurance and further of insurance against unemployment and long term care insurance. Sickness insurance is gathered into one unit with the system of health insurance and does not form a separate system. Historically, people in Germany are, for a number of years, motivated to a greater responsibility for their own health compared to the Czech Republic.

In Germany benefits are paid for working days while in the Czech Republic those are paid for calendar days. Germany has a rate of $70 \%$ while the Czech Republic has a $10 \%$ lower rate.

Nursing pay is paid up to 9 days in the Czech Republic (in case of a lonely employee 16 calendar days). In Germany it is 10 days per child aged up to 16 years per year. Assuming that in the household of the employee there is only one person who can take care of the baby, up to a maximum of 20 working days per calendar year can be withdrawn.

In the Czech Republican employee is entitled to nursing pay when he is unable to perform his job due to taking care of a child younger than 10 years. In Germany the age limit of care of a child is up to 12 years of his life. This entitlement for the employee to take care of a healthy child occurs when the school or special children's facilities, in whose care the child is, are closed due to e. g. an epidemic or quarantine.

\subsection{The Czech Republic and Slovakia}

In case of the Czech Republic and Slovakia there is a typical phenomenon that they build on a common history of social security which lasted until 1993. Later on, with the collapse of the state and the establishment of the two separate republics, the social policy of the two states began to differ.

When it happens that a Czech citizen becomes unable to work in Slovakia, his inability is registered in Slovakia until he arrives back to Bohemia. Then the inability starts to be recorded in the Czech Republic. In terms of health insurance, the duration of the disease in the Slovak Republic of the insured person is counted into the period of support.

For a Slovak citizen who has resided in the Czech Republic, the claim for sickness benefit both from the competent institution in the Slovak Republic and the Czech Republic is recorded in a special database of citizens unable to work and the documents are sent directly to the Social Insurance Company in Slovakia.

A voluntary health insurance in the Slovak Republic is legally covered in a way that a person who is neither an employee nor self-employed falls into the category of people who can apply for the voluntary health insurance. However the Czech legislation does not either know or contain this term.

The entitlement to sickness benefit in the Czech Republic in case of the self-employed occurs after 21 days of illness, while in the Slovak Republic the entitlement arises from the first day of illness.

In the case of a long-term illness (respectively in terms of an accident) the self-employed in the Czech Republic cannot run his activity.

When comparing the types of health insurance benefits, these are the same in both selected states and the entitlement conditions do not show major differences. For a substantial difference one may indicate an extension of initially equal duration for maternity allowance (mother) in the Slovak Republic from 28 (resp. 37 weeks) to 34 (resp. 43 weeks).

\section{Conclusion}

The paper dealt with the issue of public health insurance in selected countries in the European regions. It stems from the historical background of the individual states and highlights the pros and cons of a particular social system.

At all stages of the historical development of the society, social policy is an issue. It's a very flexible component of the policy, because it has a large number of variable parts that play their role in the whole social process.

Health insurance, as one of the areas of social policy, is closely associated with other areas, such as family and education policy. All the elements of the social policy are a part of support policy and the system of the state. Due to the negative demographic trends in the European region States must place ever increasing emphasis on the social sector, because it is one of the most important factors in increasing the natural growth of all countries of the European Union. 
The Czech Republic is currently looking for an effective modernization reform of the social system, even when it faces an inconsistent acceptance on the side of the public. A new social reform has been in force since 2012.

Slovakia is a country with a system that is very similar to the Czech one. It is for the reason that it has not only a common history but in the past there was a migration of people between the two countries, they have a similar speech, economic situation, lifestyle and mentality. Its modern social reform was introduced in 2004.

Finland represents a social-democratic model of a welfare state. It seeks to eradicate social differences and has a highly sophisticated care for socially weak and it is a country with the lowest unemployment rate in the European region. Social security includes state and minimum pensions and maternity pays, illness pays or family benefits. Furthermore, the amount of social security depends on the profession, which the insured person carries out.

In France, a modern social security system already begins to emerge in the second half of the 1940s after World War II but the latest social reform took place in 2005 and 2006, which meant the establishment of a separate, independent social system. Although the state has a different system for financing social benefits compared to e. g. the Czech or Slovak ones, all three countries build on the common Christian basics and principles.

German health insurance relies, when paying cash benefits, on a so-called function of contribution to the insurance, which are always covered by benefits in kind and therefore the personal coverage is much wider. In comparison to the Czech and Slovak health insurance, Germany has, due to higher economic stability of the country, a longer term of providing health benefits. In Germany this makes 78 weeks compared to 52 weeks in Slovakia or 51 weeks in the Czech Republic, respectively.

\section{References}

Čajka, P. Present Demographic Problems. In: Migrations, Mobilités, Frontières \& Voisinages. Paris: L`Harmattan, 2011, p. 115-124, ISBN 978-2-296-56363-6 (WOS)

Husenicová, L. Reflexia liberálnej teórie medzinárodných vzt’ahov v bezpečnostných štúdiách. In Bezpečnostné fórum $2013=$ Security forum 2013. Sborník vědeckých prací / volume of scientific papers / Banská Bystrica: Univerzita Mateja Bela, Fakulta politických vied a medzinárodných vzt’ahov, 2013. ISBN 978-80-557-0496-8, s. 280-287.

Chvátalová, I. a kolektiv. Právo sociálního zabezpečení v České republice a Evropské unii. Plzeň: Aleš Čeněk. 2012. s. 290. ISBN 97880-7380-374-2.

Kocourek, A. Analysis of Social-economic Impacts of the Process of Globalization in the Developing World. In Proceedings of the 11th International Conference Liberec Economic Forum 2013. 1. vyd. Liberec: Technická univerzita v Liberci, 2013. s. 297 - 306. ISBN 9788073729530.

Krebs, V. a kolektiv. Sociální politika. 3. přepracované vydání, Praha: nakladatelství ASPI, a. S. , 2005. s. 158,159

Potůček, M. Sociální politika. Praha: SLON, 1995. s. 85, 87, 97.

Svoboda, P. Úvod do evropského práva. 4. vyd. Praha: C. H. Beck, 2011. s. 243. ISBN 978-80-7400-334-9.

Tröster, P. Právo sociálního zabezpečení. Praha: C. H. Beck, 2010. s. 135, 149, 253, 358. ISBN 978-80-7400-322-6.

Ušiak, J. Integrácia Českej republiky a Slovenskej republiky do euroatlantických bezpečnostných. In Politics in Central Europe, roč. 10, c. 2/2014, ISSN 1801-3422, S. 29-43.

Tomeš, I. Předmět práva sociálního zabezpečení. In TROSTER, P. a kol. Právo sociálního zabezpečení. Praha: C. H. Beck, 2010. s. 711.

https: //www. euroskop. cz/582/sekce/evropsky-prukaz-zdravotniho-pojisteni/ [2013-02-03].

http: //www. nszm. cz/cb21/archiv/material/Svetova_deklarace_zdravi. pdf [cit. 2013-02-07].

Zacher. Grundfragen theoretischer und praktischer sozialrechtilcher Arbeit. VSSR. 1976. Act No. 187/2006 Coll. On Sickness Insurance as amended Elaborated by the EU and International Cooperation Departement of the Ministry of Labour and Social Affairs. Sociální zabezpečení osob migrujících v rámci Evropské unie: výběr textů vztahujících se k základním předpisům. 1. vydání, Praha: Ministerstvo práce a sociálních věcí. 2009. s. 8, 9, 10, 11. 